\title{
Use of biofermented plants adapted to the semi-arid region in piglet diets
}

\section{Uso de biofermentado de plantas adaptadas ao semiárido na dieta de leitões}

OLIVEIRA, Elton Roger Alves de ${ }^{1}$

https://orcid.org/0000-0003-0450-3820

MARTINS, Terezinha Domiciano Dantas ${ }^{2}$

https://orcid.org/0000-0002-4660-3814

THOMAZ, Maria Cristina ${ }^{3}$

https://orcid.org/0000-0002-5749-4051

PASCOAL, Leonardo Augusto Fonseca ${ }^{2 *}$ https://orcid.org/0000-0002-7225-5251
SILVA, José Humberto Vilar da ${ }^{2}$ https://orcid.org/0000-0001-8605-2829

SILVA, Taisa Rocha Gomes da ${ }^{4}$ https://orcid.org/0000-0001-5544-3034

BRITO, Mariany de Souza ${ }^{5}$ https://orcid.org/0000-0003-4942-3576

ALMEIDA, Jonathan Mádson dos Santos ${ }^{4}$ https://orcid.org/0000-0003-1729-6680

ALMEIDA, Jorge Luiz Santos de ${ }^{4}$ https://orcid.org/0000-0002-7186-0302

${ }^{1}$ Universidade Federal do Agreste de Pernambuco - UFAPE, Departamento de Zootecnia Garanhuns, PE/Brasil

${ }^{2}$ Universidade Federal da Paraíba, Centro de Ciências Humanas, Sociais e Agrárias, Campus III , Bananeiras-PB/Brasil

${ }^{3}$ Universidade Estadual Paulista - UNESP, Faculdade de Ciências Agrárias e Veterinárias, Jaboticabal - SP/Brasil

${ }^{4}$ Universidade Federal da Paraíba - UFPB, Departamento de Zootecnia, Rodovia 12, Areia, $\mathrm{PB} /$ Brasil

${ }^{5}$ Universidade Federal Rural de Pernambuco - UFRPE, Departamento de Zootecnia, Av. Gregório Ferraz Nogueira, Serra Talhada, PE/Brazil

*Mail for correspondence: leonardo@cchsa.ufpb.br

\section{ABSTRACT}

Two experimental tests were carried out to evaluate the inclusion of a biofermented semiarid plant mix in diets of piglets in the initial weaning phase. In the first trial, the nutritional value and digestibility of nutrients and the digestible and metabolizable energy values of the bio-fermented plants mix were evaluated. To do so, eight piglets with an initial average weight of $15.2 \pm 2.7 \mathrm{~kg}$ were used, housed in metabolic cages, and using the total collection of feces and urine. The bio-fermented plant mix diet presented $80.40 \%$ and $68.18 \%$ as digestibility coefficients for dry matter and crude fiber, respectively; $10.08 \%$ crude protein and $2,865 \mathrm{kcal} / \mathrm{kg}$ of metabolizable energy. In the second trial, the inclusion of $0,3,6$ and $9 \%$ of bio-fermented plant mix was evaluated on performance, diarrhea incidence, plasma components, weight, and length of digestive organs of piglets in the initial weaning phase. To do so, 40 piglets with an initial average weight of $12.6 \pm$ 
$3.5 \mathrm{~kg}$ were used, distributed in a randomized block design with four treatments, five replicates, and two animals per experimental unit. The inclusion of different levels of biofermented plant mix did not affect $(\mathrm{P}>0.05)$ the performance, weight, and length of digestive organs or serum parameters. However, the inclusion of bio-fermented plant reduced $(\mathrm{P}<0.01)$ the diarrhea incidence. It is concluded that bio-fermented plants adapted to the semi-arid region has the potential to be used in diets for pigs in the initial weaning phase.

Keywords: Unconventional feeds, performance, digestibility, fermentation, swine.

\section{RESUMO}

Foram realizados dois ensaios experimentais para avaliar a inclusão de biofermentado a base de plantas do semiárido na dieta de leitões na fase inicial. No ensaio I foi avaliado o valor nutricional e a digestibilidade dos nutrientes e os valores de energia digestível e metabolizável do biofermentado. Para tanto, foram utilizados oito leitões com peso médio inicial de 15,2 $\pm 2,7 \mathrm{~kg}$, alojados em gaiolas de metabolismo, utilizou-se o método de coleta total de fezes e urina. O biofermentado apresentou $80,40 \%$ e $68,18 \%$ como coeficientes de digestibilidade para a matéria seca e fibra bruta, respectivamente; $10,08 \%$ de proteína bruta e $2.865 \mathrm{kcal} / \mathrm{kg}$ de energia metabolizável. No segundo ensaio foi avaliada a inclusão de $0 ; 3 ; 6$ e 9\% de biofermentado sobre o desempenho, incidência de diarreia, componentes plasmáticos, peso e comprimento de órgãos digestivos de leitões na fase inicial. Para tanto, foram utilizados 40 leitões com peso médio inicial de 12,6 $\pm 3,5$ $\mathrm{kg}$, distribuídos em delineamento em blocos casualizados com quatro tratamentos, cinco repetições e dois animais por unidade experimental. A inclusão dos diferentes níveis de biofermentado não afetou ( $\mathrm{P}>0,05)$ o desempenho, o peso e comprimento dos órgãos digestivos e parâmetros séricos. No entanto, a inclusão do biofermentado reduziu $(\mathrm{P}<0,01)$ a incidência de diarreia. Conclui-se que o biofermentado a base de plantas adaptadas ao semiárido apresenta potencial de ser utilizado em dietas para suínos na fase inicial.

Palavras-chave: alimentos não convencionais, desempenho, digestibilidade, fermentação, suíno

\section{INTRODUCTION}

Corn is the main energetic food used in pig feed, regardless of the breeding stage. In places where the supply of this grain is insufficient, as is the case in Northeast Brazil, production costs are generally higher. Thus, it is of fundamental importance to search for alternative foods which have good nutritional characteristics and are economically viable.
The use of fodder and other roughage as an energy source to replace corn in pig feed can not only reduce production costs but also competition with human food. Therefore, some ingredients such as manioc (Manihot esculenta Crantz), maniçoba (Manihot Pseudoglaziovii Pax and Hoffman) and forage palm (Opuntia ficus-indica) can be presented as feeding alternatives for pigs. Cassava and forage palm are cultivated by producers throughout the year in the northeastern semi-arid region in Brazil for human and 
animal feed. On the other hand, maniçoba is a native plant which is very present in the semi-arid region. It presents seasonal production in the dry season in which it loses its foliage. However, the major drawback of these forages is the presence of anti-nutritional factors such as tannin (Costa et al., 2007), which compromise the nutritional values of these ingredients.

Biofermentation is based on stimulating production of microbial tissues rich in proteins and vitamins from foods of low nutritional value. There is little information about food mixtures submitted to an anaerobic fermentation process (Silva et al., 2006). This process can improve the digestibility of nutrients and reduce anti-nutritional factors, with a consequent improvement in the nutritional quality of diets.

Silva et al. (2006) were pioneers in evaluating the effect of including biofermented plants adapted to the semiarid region (palm bran and maniçoba leaves), whole cassava root, soybean meal and rumen liquid in broilers' diets. However, there are few reports on this use in pig feeding.

Thus, the objective of this study was to evaluate the nutritional value and the inclusion of different biofermented levels based on plants adapted to the semi-arid region in piglet diets in the initial weaning phase on performance, diarrhea incidence, serum parameters, weight and digestive organ length.

\section{MATERIAL AND METHODS}

Two experimental tests were carried out to evaluate including biofermented plants in the diets of piglets in the initial phase of weaning. The experimental procedures were carried out according to standard scientific norms, without compromising animal welfare rights.

Field collections of forage cactus rackets, maniçoba leaves, and of whole cassava roots were performed to produce the biofermented plant, which underwent a process of cutting into thin pieces of approximately $4 \mathrm{~cm}$. The cassava root was subjected to pre-cooking of 15 minutes to better use the starch. Then, cassava and forage palm were pre-dried in a forced circulation oven at $55 \pm 5^{\circ} \mathrm{C}$ for 72 hours.

The maniçoba, forage cactus and the whole cassava root were subsequently ground into a forage, thus facilitating a mixture with soybean meal and fresh ruminal liquid which was obtained directly from the rumen of cattle in the region's slaughterhouse. The ruminal liquid, premix and soybean meal were homogenized and deposited in polyethylene drums with a capacity of approximately 60 liters, remaining closed for one week at room temperature to favor anaerobic fermentation.

The content obtained after fermentation was pre-dried in a forced ventilation oven at $55 \pm 5^{\circ} \mathrm{C}$ for 72 hours, and subsequently stored in nylon bags at room temperature. The percentage composition of the foods used in preparing the biofermented plant mix diet is presented in Table 1. 
Table 1. Percent composition of the foods used in the preparation of the biofermented ${ }^{1}$

\begin{tabular}{lcc}
\hline Ingredients & $\begin{array}{c}\text { Content } \\
(\mathrm{Kg})\end{array}$ & $\%$ \\
\hline Forage cactus meal & 5.8 & 14.9 \\
Maniçoba leaves & 12.4 & 31.9 \\
Whole cassava root & 12.4 & 31.9 \\
Ruminal fluid & 6.6 & 17.0 \\
Soybean meal & 1.7 & 4.3 \\
Dry total & 38.9 & 100.0 \\
Pre-dry total & 19.0 & 48.9 \\
\hline
\end{tabular}

${ }^{1}$ Composition calculated and prepared in the laboratory.

\section{Experiment I}

The digestibility test of the biofermented plant mix diet was conducted in the Swine Laboratory of the Department of the Zootechnics Department of the Faculty of Agricultural and Veterinary Sciences (UNESP), Jaboticabal Campus, SP, Brazil.

Eight castrated male pigs of commercial lineage ${ }^{\circledR}$ at 50 days of age and average initial weight of $15.2 \pm 2.7 \mathrm{~kg}$ were used, homogeneously distributed in two treatments with four replicates each. The animals were individually housed in metabolic cages distributed in a randomized block design.

The experimental treatments consisted of a reference diet formulated to meet the nutritional requirements suggested by Rostagno et al. (2005), and a test diet, in which the biofermented plant mix replaced $30 \%$ of the reference diet on the basis of natural dry matter (Table 2). 
Table 2. Percent composition and nutritional values of the reference diet for piglets in the initial phase ${ }^{1}$

\begin{tabular}{|c|c|}
\hline Ingredients & Reference diet $(\%)$ \\
\hline Corn & 66.03 \\
\hline Soybean meal & 29.77 \\
\hline Dicalcium phosphate & 2.02 \\
\hline Soybean oil & 0.83 \\
\hline Salt & 0.46 \\
\hline Calcitic Limestone & 0.30 \\
\hline L-Lysine & 0.24 \\
\hline Inert $^{2}$ & 0.10 \\
\hline Mineral and vitamin suplement. ${ }^{1}$ & 0.10 \\
\hline L-Threonine & 0.08 \\
\hline DL-Methionine & 0.05 \\
\hline Butylated hydroxytoluene & 0.02 \\
\hline Total & 100.00 \\
\hline \multicolumn{2}{|l|}{ Calculated Values ${ }^{4}$} \\
\hline Crude protein $\%$ & 19.24 \\
\hline Metabolizable energy, Kcal/Kg & 3,230 \\
\hline Crude fiber $\%$ & 2.45 \\
\hline Mineral matter \% & 4.71 \\
\hline Ether extract \% & 8.10 \\
\hline Digestible lysine \% & 1.14 \\
\hline Methionine + digestible cystine $\%$ & 0.64 \\
\hline Calcium \% & 0.72 \\
\hline Available phosphorus \% & 0.40 \\
\hline \multicolumn{2}{|c|}{$\begin{array}{l}{ }^{1} \text { Nutriotional values of the ingredientes proposed by Rostagno et al. (2005). }{ }^{2} \text { Inert }=\text { Kaolin. }{ }^{3} \text { Garantee } \\
\text { levels per kg of feed: Vit. A }-4.000 \text { U.I; Vit.D3 - 220 U.I; Vit. E - } 22 \mathrm{mg} \text {; Vit. K }-0,5 \mathrm{mg} \text {; Vit B2 - 3,75 } \\
\text { mg; Vit. B12-20 mcg; Calcium pantothenic- } 12 \mathrm{mg} \text {; Niacin }-20 \mathrm{mg} \text {; Choline }-60 \mathrm{mg} \text {; Iodine - } 140 \mu \mathrm{g} \text {; } \\
\text { Selenium }-300 \mu \mathrm{g} \text {; Manganese }-10 \mathrm{mg} \text {; Zinc }-100 \mathrm{mg} \text {; Copper }-10 \mathrm{mg} \text {; Iron }-99 \mathrm{mg} .{ }^{4} \text { Values obtained } \\
\text { through laboratory analysis. }\end{array}$} \\
\hline
\end{tabular}

The experimental period lasted 12 days, with the first seven days being used for the animals to adapt to the experimental cages and diets, and the last five days to collect feces and urine using the total collection method.

The average feed intake of the animals was determined during the initial seven days in two daily meals at 8:30 am and
5:30 pm. The amount of feed consumed was weighed individually, and then water was added in a proportion of $1: 1$. Ferric oxide (1\%) was added to the feed as a fecal marker to determine the beginning and end of the collection period. The water was supplied ad libitum. 
The feces were collected and weighed twice a day in the morning and in the afternoon, packed in plastic bags and frozen. The urine was collected daily in plastic buckets, filtered, and the volume produced was measured with a $20 \%$ amount kept frozen. Next, $20 \mathrm{ml}$ of 1:1 hydrochloric acid solution and distilled water were added to each container used for urine collection to prevent microbial proliferation and nitrogen volatilization. The feces and urine of each animal were then thawed, homogenized and sampled at the end of the collection period. Next, approximately $200 \mathrm{~g}$ of feces from each sample was subjected to pre-drying in a forced circulation oven at $55^{\circ} \mathrm{C}$ for 72 hours, and subsequently ground in a knife mill equipped with $1 \mathrm{~mm}$ sieves. The urine samples were dried in Petri ${ }^{\circledR}$ dishes in a forced circulation oven at $55^{\circ} \mathrm{C}$. The feed samples were ground, following the same procedures described for the stool samples.

Dry matter (DM) analyzes were carried out on the processed feces and feed samples, which involved drying for 12 hours in an oven at $105^{\circ} \mathrm{C}$; mineral matter (MM) - drying for 12 hours in an oven at $105^{\circ} \mathrm{C}$ and burning in a muffle furnace for 3 hours; crude protein (CP) Kjeldahl method; ether extract (EE) Soxhlet fat extractor, TECNAL ${ }^{\circledR}$; crude fiber (CF), neutral detergent fiber (NDF), acid detergent fiber (ADF) according to Silva and Queiroz (2002); and crude energy (CE) - in a PARR type calorimetric pump. The densities in the urine samples were determined and $\mathrm{CE}$ analyzes were subsequently performed in a Parr and PB calorimetric pump.

The digestibility coefficients of DM, $\mathrm{OM}, \mathrm{MM}, \mathrm{CP}, \mathrm{EE}, \mathrm{CF}, \mathrm{NDF}, \mathrm{ADF}$ and $\mathrm{CE}$ were calculated, as well as the digestible and metabolizable energy and the respective digestible nutrients of the biofermented plant using equations proposed by Matterson et al. (1965).

\section{Experiment II}

The performance experiment was carried out at the Swine Laboratory of the Center for Human, Social and Agrarian Sciences (CCHSA), Campus III of the Federal University of Paraíba, Bananeiras, PB, Brazil.

A total of 40 piglets ( 20 castrated males and 20 females) of the same commercial strain $^{\circledR}$ at 42 days of age and average initial weight of $12.6 \pm 3.5 \mathrm{~kg}$ were used. The animals were distributed in a randomized block design and housed in cages with hollow plastic floors equipped with masonry feeders and pacifier-type drinkers. Four treatments with five repetitions were used, and the experimental unit was formed by two animals. The experimental period lasted 28 days.

The animals were submitted to diets with different biofermented plant mix inclusion levels of 0, 3, 6 and 9\% (Table $3)$. These inclusion levels were defined based on the energy nutritional value of the biofermented plant mix obtained in experiment I. The experimental diets were isonutritive and formulated according to the recommendations of Rostagno et al. (2005). 
Table 3. Percent and nutritional composition of experimental piglets diets in the initial phase $^{1}$

\begin{tabular}{|c|c|c|c|c|}
\hline \multirow{2}{*}{ Ingredients } & \multicolumn{4}{|c|}{ Inclusion levels of biofermented (\%) } \\
\hline & 0 & 3 & 6 & 9 \\
\hline Corn & 68.55 & 65.33 & 62.12 & 58.91 \\
\hline Soybean meal & 26.85 & 26.72 & 26.59 & 26.46 \\
\hline Dicalcium phosphate & 1.59 & 1.60 & 1.62 & 1.63 \\
\hline Soybean oil & 0.92 & 1.21 & 1.50 & 1.78 \\
\hline Calcitic limestone & 0.57 & 0.56 & 0.56 & 0.55 \\
\hline Salt & 0.41 & 0.41 & 0.41 & 0.41 \\
\hline Inert $^{2}$ & 0.09 & 0.09 & 0.09 & 0.09 \\
\hline L-Lysine $\mathrm{HCl}(78,4 \%)$ & 0.51 & 0.53 & 0.54 & 0.56 \\
\hline Vitamin premix ${ }^{3}$ & 0.10 & 0.10 & 0.10 & 0.10 \\
\hline Mineral premix ${ }^{4}$ & 0.10 & 0.10 & 0.10 & 0.10 \\
\hline DL - Methionine & 0.13 & 0.14 & 0.15 & 0.17 \\
\hline $\mathrm{BHT}$ & 0.01 & 0.01 & 0.01 & 0.01 \\
\hline L - Threonine & 0.17 & 0.18 & 0.19 & 0.21 \\
\hline Growth promoter ${ }^{5}$ & 0.01 & 0.01 & 0.01 & 0.01 \\
\hline Biofermented & 0.00 & 3.00 & 6.00 & 9.00 \\
\hline Total & 100.00 & 100.00 & 100.00 & 100.00 \\
\hline \multicolumn{5}{|l|}{ Chemical composition } \\
\hline Metabolizable energy (kcal/kg) & 3,230 & 3,230 & 3,230 & 3,230 \\
\hline Crude protein $(\%)$ & 18.79 & 18.79 & 18.79 & 18.79 \\
\hline Cálcium (\%) & 0.72 & 0.72 & 0.72 & 0.72 \\
\hline Crude fiber $(\%)$ & 2.92 & 3.05 & 3.18 & 3.30 \\
\hline Avaible phosphorus (\%) & 0.40 & 0.40 & 0.40 & 0.40 \\
\hline Lysine $(\%)$ & 1.32 & 1.32 & 1.32 & 1.32 \\
\hline Methionine+cystine (\%) & 0.72 & 0.72 & 0.72 & 0.72 \\
\hline Methionine (\%) & 0.42 & 0.42 & 0.43 & 0.43 \\
\hline L-Threonine $(\%)$ & 0.87 & 0.87 & 0.87 & 0.87 \\
\hline Sodium $(\%)$ & 0.20 & 0.20 & 0.20 & 0.20 \\
\hline
\end{tabular}

${ }^{1}$ Recommendations by Rostagno et al. (2005). ${ }^{2}$ Inert = washed sand. ${ }^{3}$ Basic product compostion: Vit. A, Vit. $\mathrm{D}_{3}$, Vit. E, Vit. $\mathrm{K}_{3}$, Vit. $\mathrm{B}_{1}$, Vit. $\mathrm{B}_{2}$, Vit. $\mathrm{B}_{6}$, Vit. $\mathrm{B}_{12}$, Niacin, Pantothenic acid, Biotin, Folic acid, Selenium, Colin, Antioxidant, Carrier E.T. Garantee levels for kg of the product: Vit. A 10.000.000 U.I, Vit. $D_{3} 4.000 .000$ U.I, Vit. E 40.000 U.I, Vit. K $2.000 \mathrm{mg}$, Vit. B $2.000 \mathrm{mg}$, Vit. B $4.000 \mathrm{mg}$, Vit. B 6 $1.500 \mathrm{mg}$, Vit. $\mathrm{B}_{12} 20.000 \mathrm{mg}$, Niacin $15.000 \mathrm{mg}$, Pantothenic acid $10.000 \mathrm{mg}$, Biotin $50 \mathrm{mg}$, Folic acid $250 \mathrm{mg}$, Selenium $250 \mathrm{mg}$, Colin $250 \mathrm{mg}$, Antioxidant $100.000 \mathrm{mg}$, Carrien E.T. $1.000 \mathrm{gr}$. ${ }^{4}$ Basci product composition : Manganese, Zinc, Iron, Copper, Cobalt, Iodine, Antioxidant, Carrier E.T. Garantee levels for $\mathrm{kg}$ of the product: Manganese $70.000 \mathrm{mg}$, Zinc $100.000 \mathrm{mg}$, Iron $40.000 \mathrm{mg}$, Copper $10.000 \mathrm{mg}$, Cobalt $200 \mathrm{mg}$, Iodine $1500 \mathrm{mg}$, Antioxidant 100.000, Carrier E.T. 1000 gr. ${ }^{5}$ Stafac 500: The base of Virginiamycin 50\%.

The leftover feed was collected, weighed and discounted from daily consumption and the individual weight of the animals was recorded at the beginning and at the 
end of the experiment to perform the production performance analysis. Based on these data, daily feed intake (DFI), daily weight gain (DWG) and feed conversion (FC) of the animals were determined throughout the experimental period.

Diarrhea incidence was determined through subjective analysis, in which the same observer classified the stool consistency daily with the score: 0 normal stools; 1 - pasty stools; 2 pasty/liquid stools; and 3 - liquid stools. Only scores 2 and 3 indicated the occurrence of diarrhea.

Blood was collected (approximately 10 $\mathrm{ml}$ ) in the morning before slaughter by puncture in the cranial vena cava in order to check the serum parameters. The collected blood was placed in test tubes without anticoagulant and subjected to centrifugation, and the blood plasma was frozen for further analysis. The plasma components determined were: total proteins $(\mathrm{g} / \mathrm{dL})$, albumin $(\mathrm{g} / \mathrm{dL})$ and creatinine $(\mathrm{mg} / \mathrm{dL})$ using LABTEST $^{\circledR}$ commercial laboratory kits.

The piglets were submitted to a 12-hour fast, desensitized by electronarcosis, and bleeding was carried out according to the procedures described for humane slaughter. The animals were eviscerated and the digestive organs (stomach, small intestine, cecum, colon, liver and pancreas) were weighed. After emptying and prior washing, the intestines were stretched and measured in length according to the methodology described by Le Gall et al. (2007).

The performance data and serum parameters were subjected to analysis of variance and subsequently to multiple linear regressions up to the third degree. The data for the treatments with the different biofermented plant mix inclusion levels was compared to the control treatment by the Dunnet test at the $5 \%$ probability level through the General Linear Model (GLM) procedure of the SAS statistical software program. The Kruskall-Wallis non-parametric test at $5 \%$ significance was used to statistically analyze the diarrhea incidence data.

\section{RESULTS AND DISCUSSION}

\section{Experiment I}

According to the obtained results, the biofermented plant mix presented a high DM digestibility coefficient $(80.40 \%)$, probably due to its high soluble carbohydrate content. However, the neutral and acid detergent fiber fraction (NDF and ADF) digestibility coefficients showed low values of $56.21 \%$ and 23.57 , respectively. This is possibly due to the high presence of cellulose and lignin (Table 4). 
Table 4. Chemical composition, digestibility coefficients, nutrient digestibility and biofermented energy in the piglet diet in the initial phase ${ }^{1}$

\begin{tabular}{lcccc}
\hline Nutrients and energy & $\begin{array}{c}\text { Chemical } \\
\text { composition }\end{array}$ & $\begin{array}{c}\text { Digestibility } \\
\text { coefficients }\end{array}$ & $\begin{array}{c}\text { Nutrients } \\
\text { and } \\
\text { Digestible } \\
\text { energy }\end{array}$ & $\begin{array}{c}\text { Metabolizable } \\
\text { energy }\end{array}$ \\
\hline Dry matter (\%) & 89.76 & 80.40 & 72.17 & \\
Organic matter (\%) & 83.97 & 82.56 & 69.33 & \\
Mineral matter (\%) & 5.79 & 49.05 & 2.84 & \\
Crude protein (\%) & 10.08 & 44.25 & 4.46 & \\
Ether extract (\%) & 2.82 & 42.20 & 1.19 & \\
Crude fiber (\%) & 6.60 & 68.18 & 4.50 & \\
Neutral detergent fiber (\%) & 18.34 & 56.21 & 10.31 & \\
Acid detergent fiber (\%) & 10.52 & 23.57 & 2.48 & \\
Gross energy (Kcal/Kg) & 3,749 & 78.76 & 2.952 & 2,865 \\
\hline
\end{tabular}

${ }^{1}$ Values expressed in natural matter.

Piglets in the initial phase do not yet present complete digestive system development, which makes it difficult to break down several fibrous components. Thus, the insoluble fractions quantified by the NDF and ADF analyzes are made up of insoluble hemicellulose, cellulose and lignin, and are presented as nutrients of low digestibility because they have low fermentability in the digestive tract of swine (Dierick, 1989).

The crude protein $(10.08 \%)$ and crude fiber $(6.60 \%)$ values in the respective study were lower than those found by Silva et al. (2006), who found values of $15 \%$ and $9.4 \%$ for crude protein and crude fiber, respectively. However, the values found by these same authors for dry matter $(88 \%)$ and ether extract $(3 \%)$ were similar to those of the present study.

The variation in the chemical composition of the biofermented plant mix can be explained due to the genetic variability of cassava, maniçoba, forage cactus and soybean, as well as the processing techniques to which they were submitted. The rumen liquid used may also have been a probable source of variation, since the microbiota composition is dynamic and can be modified due to several factors such as the slaughter age and the food offered to the animal.

The great variation which occurs in the food digestibility between different tests may be related to its physical-chemical composition (particularly fiber content). The age, composition and variety of products used in making the biofermented plant mix, as well as the experimental design used can interfere with digestibility values. In addition, body weight, age and genetics of animals can also influence digestibility (Noblet and Le Goff, 2001; Kutschenko, 2004). The biofermented plant product showed good values for crude $(3,749 \mathrm{Kcal} / \mathrm{Kg})$, digestible $(2,952 \mathrm{Kcal} / \mathrm{Kg}) \quad$ and metabolizable energy $(2,865 \mathrm{Kcal} / \mathrm{Kg})$, 
configuring itself as an energetic food. However, these values were lower than that of corn which has 3,936, 3,469 and $3,390 \mathrm{Kcal} / \mathrm{kg}$ of crude, digestible and metabolizable energy, respectively, but higher than those of wheat bran containing 2,481 and 2,370 Kcal/Kg of digestible and metabolizable energy for pigs, respectively (Rostagno et al., 2017).

The inclusion of different levels of biofermented plant mix adapted to the semi-arid region did not affect $(\mathrm{P}>0.05)$ the productive performance variables of: daily feed intake, daily weight gain and feed conversion of piglets in the initial phase (Table 5).

Table 5. Daily feed intake, daily weight gain, feed conversion and incidence of piglet diarrhea in the initial phase feed different levels of biofermented from plants adapted to the semi-arid region

\begin{tabular}{|c|c|c|c|c|c|c|}
\hline \multirow{2}{*}{ Variables } & \multicolumn{4}{|c|}{ Inclusion levels of biofermented (\%) } & \multirow{2}{*}{$\mathrm{P}^{1}$} & \multirow{2}{*}{$\begin{array}{l}C V \\
(\%)^{3}\end{array}$} \\
\hline & 0 & 3 & 6 & 9 & & \\
\hline Daily feed intake, $g$ & 1223.76 & 1296.58 & 1273.67 & 1317.96 & $\mathrm{NS}^{2}$ & 7.97 \\
\hline Daily weight gain, $g$ & 703.21 & 749.28 & 737.7 & 730.89 & NS & 9.08 \\
\hline Feed conversion & 1.78 & 1.74 & 1.74 & 1.81 & NS & 8.13 \\
\hline Incidence diarrhea & $5.52 \mathrm{a}$ & $0.00 \mathrm{c}$ & $1.38 \mathrm{c}$ & $4.83 b$ & 0.05 & \\
\hline
\end{tabular}

${ }^{1}$ The means did not show significant differences when compared to the Dunnet test $(\mathrm{P}>0,05) .{ }^{2} \mathrm{Not}$ significant. ${ }^{3}$ Coefficient of variation. ${ }^{4}$ Scores 2 and 3 were considered to be diarrheal. The averages were compared by the Kruskal Wallis $(\mathrm{P}<0,05)$.

The absence of statistical difference for the performance variables suggests that the nutritional quality of the diets was maintained, regardless of the inclusion level of the biofermented plant mix, thus being well accepted by the animals.

In this context, a biofermented plant compound was tested in the feed of broilers, and the authors concluded that the biofermented plant mix affected the performance of the chickens, however it was not toxic for the animals. Thus, it can be an option in the diet composition, and can be added up to a level of $10 \%$ for broilers from 22 to 42 days of age (Silva et al., 2006).

However, it was found that the inclusion of biofermented plant mix positively influenced $(\mathrm{P}<0.05)$ the control of diarrhea in piglets in the initial weaning phase, regardless of the level used (Table 5).
It was also found that piglets fed with $3 \%$ biofermented plant mix did not present diarrhea and were statistically equal to those that consumed the diet with $6 \%$ biofermented plant mix. In contrast, animals fed without the biofermented plant mix had the worst results. Thus, according to Lilienthal et al. (2002), the best fecal consistency is indicative of good digestibility and better use of food. It is noteworthy that diarrhea is not a disease but a symptom characterized by above normal excretion of liquid feces. There are countless causes of diarrhea, among which we can mention: the presence of greater amounts of low absorption solutes with osmotic activity within the intestinal lumen (osmotic diarrhea), such as carbohydrates and proteins; increased water retention in the intestinal lumen due to the abnormal transport of ions from the intestinal 
epithelial cells (secretory diarrhea); problems in the motility of the gastrointestinal tract; inflammatory processes which increase fluid secretion by the intestinal mucosa; and changes in intestinal morphometry such as greater hyperplasia in crypt cells and atrophy of the villi which compromise digestive and absorptive processes (Lima et al., 2009). Biofermentation proved to be effective considering that diarrhea is one of the main problems that affect piglets in the nursery phase. The biofermented plant mix probably had functions similar to prebiotics; however, subsequent studies need to be carried out to better elucidate this hypothesis.

The inclusion of biofermented plant mix adapted to the semi-arid region in the piglet diet in the initial weaning phase did not influence $(\mathrm{P}>0.05)$ the serum parameters evaluated (Table 6).

Table 6. Serum parameters of piglets in the initial phase feed with different levels of plant-based biofermentated adapted to the semi-arid region

\begin{tabular}{lcccccc}
\hline & \multicolumn{7}{c}{ Inclusion levels of biofermented (\%) } & & \\
\cline { 2 - 5 } & & & & & & \\
Variables & 0 & 3 & 6 & 9 & $\mathrm{P}^{1}$ & $\mathrm{CV}, \%^{3}$ \\
\hline Total proteins, $g / d L$ & 4.34 & 4.00 & 3.66 & 3.66 & $\mathrm{NS}^{2}$ & 14.30 \\
Albumin, $g / d L$ & 2.51 & 1.96 & 2.88 & 3.80 & $\mathrm{NS}$ & 21.10 \\
Creatinine, $m g / d L$ & 0.99 & 1.00 & 0.99 & 1.00 & $\mathrm{NS}$ & 0.73 \\
\hline
\end{tabular}

${ }^{1}$ The means did not show significant diferences when compared to the Dunnet $(\mathrm{P}>0,05) .{ }^{2}$ Not significant. ${ }^{3}$ Coefficient of variation.

The values found for albumin and creatinine are in agreement with the biochemical constituent's Table of Fraser (1991), in which he found mean albumin values between 2.3 to $4 \mathrm{~g} / \mathrm{dL}$ and creatinine from 0.8 to $2.3 \mathrm{mg} / \mathrm{dL}$; however, the values of total proteins according to this author vary between 5.8 to $8.3 \mathrm{~g} / \mathrm{dL}$, being higher than those found in this work. The total protein content was probably reduced due to the low protein digestibility coefficient in piglets fed with the biofermented plants adapted to the semi-arid region.
It is the digestive and absorptive processes of amino acids in the diet which will interfere with the concentration of proteins present in the plasma, whereas any difficulty in these processes may result in a decrease in the concentration of total plasma proteins (Fabian et al., 2004).

The inclusion of different biofermented plant mix levels in the piglet diet in the initial weaning phase did not change $(\mathrm{P}>0.05)$ the weights of the evaluated digestive organs (Table 7). 
Table 7. Digestive organ weights and intestinal lenght of piglets in the initial phase feed different levels of plant biofermented

\begin{tabular}{|c|c|c|c|c|c|c|}
\hline \multirow{2}{*}{ Organs } & \multicolumn{4}{|c|}{ Inclusion levels of biofermented (\%) } & \multirow{2}{*}{$\mathrm{P}^{1}$} & \multirow{2}{*}{$\mathrm{CV}(\%)^{3}$} \\
\hline & 0 & 3 & 6 & 9 & & \\
\hline Stomach $(g)$ & 483 & 490 & 525 & 497 & $\mathrm{NS}^{2}$ & 21.07 \\
\hline Liver $(\mathrm{g})$ & 850 & 773 & 963 & 803 & NS & 14.24 \\
\hline Pancreas $(\mathrm{g})$ & 150 & 112 & 100 & 105 & NS & 22.10 \\
\hline Small intestine $(\mathrm{g})$ & 1467 & 1585 & 1557 & 1397 & NS & 10.39 \\
\hline Large intestine $(\mathrm{g})$ & 1210 & 1307 & 1692 & 1327 & NS & 22.39 \\
\hline \multicolumn{7}{|l|}{ Lenght $(\mathrm{m})$} \\
\hline Small intestine & 15.07 & 14.58 & 13.13 & 14.17 & NS & 4.98 \\
\hline Large intestine & 3.69 & 3.58 & 4.13 & 3.63 & NS & 13.14 \\
\hline
\end{tabular}

The variation in the weights of digestive organs is closely related to the energy and/or protein consumption of the diets, whereas when supplied in similar quantities (meaning isoenergetic and isoproteic diets), the weights of these structures tend to be similar (Rao \& McCracek, 1992). In addition, it would be necessary to supply these ingredients in a high proportion for a longer period of time than was performed in this experimental trial, thus causing a high metabolic stress and possibly different results.

Since the weight and length of digestive organs are closely correlated with the performance and development of the animals (as seen in Table 5), there was no influence of including the biofermented plant mix on consumption or weight gain.

However, characteristics of the ingredients related to both their nutritional value as well as their physical characteristics in the digestive tract can influence the weight of the organs, increasing the weight, volume and/or capacity of pigs' gastrointestinal tract, and the fibrous fraction of the diet can promote possible changes in motility and morphology of the gastrointestinal tract (Bach Knudsen et al., 1993).

\section{CONCLUSION}

The biofermented mix of plants adapted to the semi-arid region showed 2,865 $\mathrm{Kcal} / \mathrm{kg}$ of metabolizable energy and nutritional values which make it a possible ingredient to be added in up to $9 \%$ in diets for piglets in the initial weaning phase.

\section{REFERENCES}

ARRUDA, J.C.B.; MARTINS, T.D.D.; SILVA, J.H.V. et al. Desempenho de leitões submetidos a diferentes níveis de substituição da proteína do farelo de soja pela proteína do ovo desidratado. Acta Scientiarum Animal Science, v.30, n.4, p.401-405, 2008.

COSTA, F.G.P.; OLIVEIRA, C.F.S.; BARROS, L.R. et al. Valores energéticos do feno de jureminha, feijão 
bravo e maniçoba para aves. Revista Brasileira de Zootecnia., v.36, n.4, p.813-817, 2007.

DIERICK, N. A. Approach to the energetic importance of fibre digestion in pigs. I. Importance of fermentation in the overall energy supply. Animal Feed Science and Tecnhology, v.23, n.1-3, p.141-167, 1989.

FRASER, C. M. Manual merk de veterinária. São Paulo: Roka, 1803p. 1991.

KUTSCHENKO, M. Efeito de diferentes graus de moagem da casca de soja sobre a digestibilidade dos nutrientes e o desempenho de suínos na fase inicial. 40p. Dissertação (Mestrado em Zootecnia) - Universidade Estadual de Maringá, Maringá, 2004.

LE GALL, M.; QUILLIEN, L.; SÈVE, B. et al. Weaned piglets display low gastrointestinal digestion of pea (Pisum sativum L.) lectin and pea albumin.

Journal of Animal Science, v.85, p.2972-2981, 2007.

LILIENTHAL, L.K.K.; MERCHEN, N.R.; GRIESHOP, C.M. et al. Selected gelling agents in canned dog food affect nutrient digestibilities and fecal characteristic of ileal cannulated dogs. Journal of Nutrition, v.132, p.17141716, 2002.

LIMA G.J.M.M.; MORES N. \& SANCHES R.L. As diarreias nutricionais na suinocultura. Acta Scientiae Veterinariae. 37 (Supl 1): s17-s30, 2009.
LOHMANN, A.C.; POZZA, P.C.; POZZA, M.S. dos S. et al. Níveis de valina digestível para suínos machos castrados dos 15 aos $30 \mathrm{~kg}$. Archivos de Zootecnia, 61(234), p. 267-278, 2012.

MATTERSON, L.D.; POTTER, L.M.; STUTZ, M.W. et al. The metabolizable energy of feed ingredients for chickens. Research Reporting, v.7, p.11-14, 1965.

NOBLET, J. \& LE GOFF, G. Effect of dietary fibre on the energy value of feeds for pigs. Animal Feed Science and Tecnhology, v.90, p.35-52, 2001.

ROSTAGNO, H.S.; ALBINO, L.F.T.; DONZELE, J.L. et al. Tabelas brasileiras para aves e suínos: composição de alimentos e exigências nutricionais. 2. ed. Viçosa:

Universidade Federal de Viçosa, 186p. 2005.

ROSTAGNO, H. S. et al. Tabelas

Brasileiras para Aves e Suínos: composição dos alimentos e exigências nutricionais. 4. ed., Viçosa: UFV, p. 443-444. 2017.

SAS-Statistical Analysis System Institute. SAS user's guide: statistic. Cary: SAS Institute, 1997.

SILVA, D. J. \& QUEIROZ, A. C. Análise de alimentos: Métodos químicos e biológicos. 3rd ed. Imprensa Universitária/UFV: Viçosa. 2002.

SILVA, J.H.V.; COSTA, M.R.; COSTA, S.M.V. et al. Avaliação do biofermentado à base de plantas nativas 
semi-áridas (BIONAT) na ração de frangos de corte. In: CONGRESSO
NORDESTINO DE PRODUÇÃO

ANIMAL, 4., 2006. 